\title{
Transatlantica
}

Revue d'études américaines. American Studies Journal

\section{Nothing Risked, Nothing Gained: Richard Powers' Gain and the Horizon of Risk}

\section{Aaron Jaffe}

\section{(2) OpenEdition}

1 Journals

\section{Electronic version}

URL: https://journals.openedition.org/transatlantica/4632

DOI: 10.4000/transatlantica.4632

ISSN: 1765-2766

\section{Publisher}

Association française d'Etudes Américaines (AFEA)

\section{Electronic reference}

Aaron Jaffe, "Nothing Risked, Nothing Gained: Richard Powers' Gain and the Horizon of Risk",

Transatlantica [Online], 2 | 2009, Online since 14 February 2010, connection on 02 February 2023. URL: http://journals.openedition.org/transatlantica/4632 ; DOI: https://doi.org/10.4000/transatlantica.4632

This text was automatically generated on 2 February 2023.

\section{(c) (i) (9)}

Creative Commons - Attribution-NonCommercial-NoDerivatives 4.0 International - CC BY-NC-ND 4.0 https://creativecommons.org/licenses/by-nc-nd/4.0/ 


\title{
Nothing Risked, Nothing Gained: Richard Powers' Gain and the Horizon of Risk
}

\author{
Aaron Jaffe
}

1 For a recent, real life version of this theme, gain without risk, it would be hard to improve on No Impact Man. In early 2007, his story swept through the media. Somewhere in Manhattan, the story ran, a writer and his family were contriving a way to live having "no impact" on the Earth. To counteract the greenhouse catastrophe, they adopted a total do-it-yourself, or, d.i.y., ethos. They no longer bought thingsexcept provisions at the farmer's market produced "within 250 miles-a day's round trip." For light, one bulb supplemented by beeswax candles. Every deprivation becomes a kind of gain. To minimize waste, vermicomposting the food scraps, toting receptacles made of natural materials, hand-washing diapers using "ethical" cleaning concoctions. In short, all the consumer perks were forsworn, everything contributing to the carbon footprint verboten or compensated for with donations to environmental charities and carbon-trading schemes.

2 German sociologist Ulrich Beck's theory of second modernity can help us understand this behavior. No Risk Man can be seen as a paragon of Beck's "risk society." For Beck, the decisive shift between the two modernities entails a transition of cultural logic from wealth distribution (or, "goods") to risk distribution (or, "bads"). Modernity stops being about extending the benefits of detraditionalizing modernization and instead becomes reflexive. It increasingly becomes "its own theme," concerned not with instrumental rationality but with managing its own ambivalent side-effects, "discovering, administering, acknowledging, avoiding or concealing [...] hazards" (Risk Society 19-20). In short, an epistemological New Deal: knowledge retains its cardinal powers, yet, as seemingly "harmless things, wine tea, pasta, etc., turn out to be dangerous, the status of knowledge subtly and irrevocably changes [...]. The once highly praised sources of wealth (the atom, chemistry, genetic technology and so on) are transformed into unpredictable sources of danger" (51). 
3 The case for second modernity, then, depends on two observations about time and space, which should be of special interest to readers of Powers' novel. Contaminated relations detected in the everyday experience of things implicate experiences of the past and present and relations of the bodies insides and outsides (Cosmopolitan Vision 7). Risk shreds promissory notes of cause and effect with wide ranging, new, and frequently paradoxical implications for identity, society and politics. Beck underscores that

[t]he center of risk consciousness lies not in the present, but in the future. In the risk society, the past loses the power to determine the present. Its place is taken by the future, thus, something non-existent, invented, fictive as the "cause" of current experience and action. (33-34)

Under first modernity, it is the past that determines the future. Yet, if the modernist break with tradition is the arch form consciousness takes under first modernity, in the second release, the idea of the present as a leave-taking of the past itself becomes passé. The present is now (over-) determined by the future.

\section{A Tale of Two Soaps}

5 It seemed not too long ago that every pomo-culture critic worth her salt needed a theory of Fight Club ${ }^{1}$. Either the David Fincher film or the Chuck Palahniuk novel sufficed. Properly speaking, this one is an anti-Fight Club argument; Power's Gain is almost perfectly anti-Palahniukian. The reason Fight Club may make fine whetstone for criticism is not so much that it has been thoroughly hashed over by would-be critics but that it comes with a ready-made thesis in tow. In the case of Fight Club, the message that the individual is fragmented-or, maybe just feminized-by commodity culture. Homosociality cum blood sport can repair the commons. The fist in the face heals the whole earth. Gain rejects this pseudo-utopian thesis out of hand-the role of the individual consumer in the corporation is damage, complicity, exposure to risk.

Gain and Fight Club were both published within about a year. Both are about, in one synoptic word, soap. The book covers attest to this commonality. On Powers', a female hand with a French manicure, in soft focus, holds an ovoid bar of soap, creamy white, embossed with title of the novel' ${ }^{2}$; on Palahniuk's, the composition is similar, but this time it is a hard-edged, square bar, Neutrogena-like in its translucence, displaying the title ${ }^{3}$.

7 On the film poster, the contrasting soap presentation is more pronounced ${ }^{4}$. The man hands-to wit, Brad Pitt's bruised knuckles-holding an oddly pink cake, the same color as Wyndham Lewis's avant-garde magazine BLAST. Tag-line: "Mischief. Mayhem. Soap." Soap plays a key role as a symbol. In Fight Club, "making soap" means revolutionary d.i.y. lifestyle, cleansing, self rendering. Tellingly, Pitt's pose holding a bar of soap echoes the flashing of a badge; it is an initiation, a secret handshake. Pointedly, in a critical episode, he teaches the narrator to make soap, using, in the movie anyway, liposuctioned fat. This is an inset detail: soap equals purgation. The connection depends on semiotic similarity. The alternative, underground, economic logic points to any number of anarchist's cookbooks: "With enough soap," Tyler says, "you could blow up the whole world" (72). Soap is explosive, cleansing the individual of consumerist corruption: Soap means something else to us-Tyler tells Project Mayhem-it is a symbol of our shared project. 
Compared with symbolic soap in Fight Club, soap in Gain is allegorical: a full blown illustration, a metonymy, contiguous with the rise of the corporation that sells it and then does not. Before it is Clare International, it is Clare Candle and Soap Corporation. The substance of soap in Gain is also the substance of the issue. As one of the many extraneous sections in Gain puts it: "Soap is a desperately ordinary substance to us. It is almost as omnipresent as air and water. It is so common that it is difficult to imagine life without it... Not until modern industry came along to demonstrate the virtues of mass production did soap become the property of all the people" (21). Like Fight Club, Gain includes a detailed discussion of the soap making process:

Here was a substance, grease's second cousin. Yet something had turned waste inside out. Dirt's duckling transformed into salve's swan its rancid nosegay rearranged into aromatic garland. This waxy mass, arising from putrescence, became its hated parent's most potent anodyne.

[...] To make their first run, they paid cash for a quantity of fine rendered fat. Thereafter, they sought suppliers who would trade good tallow for excellent soap, a pound for a pound. As their process made two pounds of soap for each pound of introduced fats, they would have half their run left over to pay for alkali, keep equipment repaired, and put bread on their own tables. (34-35)

9 The multivalent word of Powers' title-gain-may find its most straightforward application in this passage. Gain is the winnings, the supernaturally profane increase, which, other than God, only the corporation is positioned to make scalable for its constituent parties and shareholders. In Fight Club, where the corporation is merely symbolized by skyscrapers, this kind of transaction is not so much narrativized as it is displaced; indeed, the organizational gain, its incorporation and complexification, is not rendered in terms of a soap imperium but in terms of Fight Club franchises.

10 For what it is worth, Powers' original soap-maker, the Irish immigrant Ennis, has all the preternatural knowledge about soapmaking, but he is not able to go it alone without backers. He is an expert; he is also significantly a melancholic idealist. If not Tyler Durden or No Impact Man, somehow in the soap maker's fraternity he is a distant relation, a far more enigmatic figure than the early Clares, surely, because of his connection to scientific know-how. Ennis just wants to sell a perfect object that he knows how to make, which, it seems, is also an impossible commodity-a bar of soap that costs more to make than he get for it: "a perfect soap that you could go and sell below cost" (33).

11 The magic of soap is not simply the technical knowledge of chemical engineeringbetter living through chemistry. It is the sleight-of-hand of a perceived gain without visible risk (from sin to skin cleansing) otherwise described as the impact of consumer engineering (211). You know, better living through marketing:

Only when Resolve [Clare] gazed upon that first [batch of finished soap] did he consider their odd position. Their own customers would be their chief competition. Caked soap was still an expensive substitute for the slippery paste that every home could yet make as a matter of course. The Clares' soap had to teach thrifty New England how smelly, difficult, and undependable home soapmaking had always been. (35)

12 So, unlike in Fight Club, the stuff you don't need, the manufactured "needs" which the hidden persuaders foist on you, aren't IKEA chipboard end tables-mere symbols of an 
abstract consumerism-it is the altered epistemological status actually carried by a real thing, namely soap. Powers frames this scene-the primal scene of the presentation of soap, as it were-precisely as an occasion of epistemological loss-a process through which technical knowledge (i.e., the household knowledge of making cheap cleansers) is lost. The story of the Clare Corporation is a gain wagered on less knowledge about how things are made, how they work, what they may or may not do to you.

Gain as a novel is, quite fittingly, more than the sum of its parts. Basically, its parts are two narratives-neither of which are really the substrate of great novels, if you can still say such things. Place this brundlefly in a teleporter to disentangle, neither of the generic threads would survive long. The first concerns the rise of the Clare Corporation; the second concerns the decline of Laura Rowan Bodey, a single divorced woman diagnosed and unsuccessfully treated for ovarian cancer. Generically, the parts derive from biography-like non-fiction forms: the corporate history/commodity bio and the cancer memoir, respectively. The parts alternate and are separated by a thin diacritical lozenge-a soap-like sliver separating the generic constituents. Neither part is epistemologically sufficient.

ird element, then, is all the extraneous, expositional stuff, scraps of information, waste, signs, advertising, research, adding to this sense of narrative insufficiency. That is, a key piece is missing-a lost reel from both narratives, which is, simply put, the scene of critical, epistemological contact-fateful and fatal-between the first narrative and the second more than the coincidence of their shared time in Lacewood, Illinois, where Clare has a manufacturing plant. That lynchpin moment of contamination of the individual by the evil corporation (familiar enough from Silkwood to The Incredible Shrinking Woman; Spiderman to Michael Clayton) is, tellingly, left un-narrated. When did it happen to her? Not even a court ruling does the trick, because it is a class action. Risk is only adjudicated as it is measured: in aggregate humanity. "As the pamphlets say: the numbers stand for groups, not for individuals [...]. [M]aybe it means, repeat the next five years forever, and on average, a fifth of her will die" (102).

The unlikelihood of both novels as novels goes back to the situations of their organizing agents. First, a post-human body made indestructible by law: it "far outstripped the single life's span" (154). "Enterprise's long evolving body now assembled good beyond any private life's power to manufacture" (155). Powers makes this point emphatically:

The law now declared the Clare Soap and Chemical Company one composite body: a single, whole, and statutorily enabled person [...]. If the Fifth and Fourteenth Amendments combined to extend due process to all individuals, and if the incorporated business had become a single person under the law, then the Clare Soap and Chemical Company now enjoyed all the legal protections afforded any individual by the spirit of the Constitution.

And for the actions of that protected person, for its debts and indiscretions, no single shareholder could be held liable. (158-159)

Second, a single, female body, made low by hidden causes, causes suspected to be linked to either a life spent in Lacewood and or one of many consumer conveniences provided by Clare or one of its competitors. In this sense, Laura Rowan Bodey-her exhusband calls her "lo"-a lowly, ruined body, is the individual human as loss, eventually reduced to materializing her failing cancer-addled mind with post-it notes. Neither of these two entities-and I realize it is distasteful to describe Laura in these 
terms, but I am convinced this is Powers' point-is possible as a protagonist. It is decidedly not a novel about a woman vs. a corporation. Neither one has so much a comprehendible struggle-agon in the classical sense-as a contrasting risk position. The sum of the parts is no more and no less than the dual disclosure of their respective risk positions: the corporation is an entity with aggregated risk security and an individual is an entity with absolute risk exposure. The normalization-or, routinization-of risk in the corporation is put against a position of absolute exposure to risk; a position in which risk is so widespread it is literally the water she swims in.

The corporation is shown to have no malice for Laura. Indeed, if it is not exactly indifferent to her life story, it sees itself twinned with her fate:

Clare, with its allies Lever, Colgate, and Proctor and Gamble, scrubbed out of existence those German and Jap cottage industries that hoped to covert the world to soap made from unspeakable sources. Clare Soap and Chemical won the war [...]. Or rather, Mrs. Consumer did. She won in the pantry and on the stove top and in the medicine chest. (321)

Back to those feminine hands with French manicure, presenting the bar of soap to herself. Implicating in an advertising feedback loop cum death cult, the identification between Laura and Mrs. Consumer is mutual:

Laura reads [Shopping for Safety] in tiny increments, in those moments when her head is clear and her eyes can focus. As far as she can make out, nothing is safe. We are all surrounded. Cucumber and squash and baked potato. Fish, that great health food she's been stuffing down the kids for years. Garden sprays. Cooking oils. Cat litter. Dandruff shampoo. Art supplies. Varnish. Deodorant. Moisturizers. Concealers. Water. Air. The whole planet, a superfund site. Life causes cancer. (284)

Here, she is also a cognate of the wife of Ennis, the early Irish soap maker, who dies during the passage to America. The moment of Clare's investiture as business enterprise-a collective activity-pays for the coffin of one dead wife. It is an ambivalent legacy.

This continuity is one of the reasons I think it is a mistake to read the soap bar as a symbolic warning of corporate wrongdoing. Another is this passage:

The newspapers, Don, the lawyers: everybody outraged at the offense. As if cancer just blew in through the window. Well, if it did, it was an inside job. Some accomplice, opening the latch for it [...]. She brought them in, by choice, toted them in a shopping bag. And she'd do it all over again, given the choice. (304).

No longer her home, this place they have given her to inhabit. She cannot hike from the living room to the kitchen without passing an exhibit. Floor by Germ-Guard. Windows by Cleer-Thru. Table by Colonial-Cote [...]. She vows a consumer boycott, a full spring cleaning. But the house is full of them. It's as if the floor she walks on suddenly liquefies into a sheet of termites [...]. Clare hiding under the sink, swarming her medicine chest, lining the shelves in the basement, parked out in the garage. Piled up in the shed [...]. Her vow is hopeless. Too many to purge them all. Every hour of her life depends on more corporations than she can count. And any spray she might use to bomb the bugs would have to be Clare's, too. (304) 
The allegory in Gain about the calculus of risk is chiefly epistemological. It is what we think we know about the unknown that counts: "people view themselves simultaneously as part of a threatened world and as part of their local situations and histories." Although the knowledge this involves is not exclusively ecological-it is also economic and terroristic-future ecological catastrophe may be understood as its governing theme. Risk-something that is not stable in terms of knowledge-becomes a general theme of knowledge. Postmodernity presupposes epistemological uncertainty, second modernity does not. The subject to risk is not a postmodern hero-not a subject of postmodernity as it is frequently construed in terms of epistemological uncertainty or ethical relativism. She feels subject to threats that her lay knowledge cannot adequately access but feels a categorical imperative to address them. Nor is she not anti-science. She cannot be. Her knowledge of threats requires "the 'sensory organs of science'-theories, experiments, measuring instruments-in order to become visible or interpretable as threats at all" (Risk Society 162). Donald Rumsfeld's much ridiculed remark about "known knowns, known unknowns, and unknown unknowns," concerning military risk in the second Gulfwar, applies here as a critical idiom. As Beck puts it: "unknown and unintended consequences come to be a dominant force in history and society" (22). The invisible threats-toxins, radiation, CO2, inflation, invisible enemies next door-are not private risks experienced in the present, but socialized risks to be or not to be experienced, known unknowns and unknown unknowns that may or may not be deferred in the future after one's death.

\section{Home Alone}

The basic, assumed human unit in second modernity is neither nuclear family nor the childless couple but the single person (122). While Beck describes children as "the last remaining, irrevocable, un-exchangeable primary relationship," he also notes that they do little more than facilitate the individual's exposure to risk. In fact, individualization, for Beck, has not so much to do with consciousness or identity formation in the romantic sense, nor does it really follow from employment position. He equates it instead with what he calls "the objective life situation"-which is something like orientation toward employment. Here is one last image of a hand, presenting the trademark fleck of cleanser ${ }^{5}$.

Individualization means the social separation of adults from others (parents, school ties, etc.), "the variation and differentiation of lifestyles and forms of life, opposing the thinking behind the traditional categories of large-group societies-which is to say, classes, estates, and social stratification" $(128,88)$. Paradoxically, the moment of individualization also represents the defining scene of socialization:

The individual himself or herself becomes the reproduction unit of the social in the life world. What social is and does has to be involved with individual decisions. Or put another way, both within and outside the family, individuals become agents of their educational and market-mediated subsistence and the related life planning and organization. Biography itself is acquiring a reflexive project. (90)

24 A single, solitary unit enters a labor market that demands foremost mobility and flexibility. And, given this market's dependence on "flexible, pluralized underemployment" and demographics (discussed at length by Beck) that tend to situate women in this profile, Risk Woman may in fact be a more accurate gender

Transatlantica, 2 | 2009 
designation. In short, the market requires her to adopt a risk position. The substance of this social reality is liquid, resembling Zygmunt Bauman's liquid modernity-a connection Beck has recently acknowledged. Her education remains a critical locus for second modernity, the very reason education serves as the best means of achieving a favorable risk position is because it creates human liquidity. Like Simmel's money, educational credentials loosen local ties and enable biographies to be composed on a colossal scale via non-local networks: "By becoming independent from traditional ties, people's lives take on an independent quality which, for the first time, makes possible the experience of a personal destiny" (94).

And, it is thus not surprising that the figure of Laura-dying of a cancer that may or may not be caused by the biographical proximity to Clare's corporate history-provides a paradigmatic example for this process. Indeed, the following passage of Beck's is striking not only because it simultaneously overvalues and undervalues the individual biography but also because it provides a rather perceptive description of the modernist author function:

All [the] experts dump their contradictions and conflicts at the feet of the individual and leave him or her with the well intentioned invitation to judge all of this critically on the basis of his or her own notions. With detraditionalization and the creation of global media networks, the biography is increasingly removed from its direct spheres of contact and opened up across the boundaries of countries and experts of a long-distance morality which puts the individual in the position of potentially having to take a continual stand. At the same moment as he or she sinks into insignificance, he or she is elevated to the apparent throne of world-shaper. (Risk Society 137)

This is none other than the predicament of No Impact Man, elevated to the apparent throne of world-shaper as he sinks into insignificance. Tellingly, it also captures the aim of his No Impact project: the epic side of doing nothing. The following statement, which is nominally about one of his project's many moments of self-doubt, effectively individualizes this sentiment in all its vertiginous impossibility:

I get confused. If everybody on the whole planet decided to commit suicide, which in a way, they have, would it be the right thing to do to not join in? What's so great about trying to be right if it keeps you separate? It seems like there is something precious that has to do with holding yourself above or not just joining in and being part of. I don't know. I'm suddenly realizing that this whole [No Impact] project could be pretty damn hard.

\section{Dare to Know the Risks}

No Impact Man, for what it is worth, approaches his project with an autodidact's zeal for designing and describing experiments. He is constantly soliciting information to these ends from the web equivalent of the Whole Earth Catalogue. "Of course," he blogs, "the scientists will tell you that [no net environmental impact] doesn't work, but it isn't intended to work so much scientifically as it is to work philosophically." And, as the comments on the site so often document, the scientists do take issue with the science. Here, the specific problem No Impact Man has in mind is, I think, the futility of the urban dweller of the global north (even in their collective efforts) neutralizing the great carbon offense of our time, the hydrocarbon economy in all its unconstrained, coal-powered productivity. Scientists alone can't tell you this, though, neither can political policy wonks, nor economists, nor any single professional knowledge expert, 
including philosophers. They can't resolve this “interdependency crisis" between ecological, economic, and terroristic domains. The claim that the project is driven by philosophical motives is not that it turns out a saving framework but a related story. The philosopher proper who comes up most prominently on the site is Kant:

Now I am no expert on philosophy, but my friend Eden tells me that Kant considered the best test of morality to be the Formula of Universal Law. He wrote, "act only on that maxim whereby you can at the same time will that it should be a universal law." Or to translate, each of us should live our lives in such a way that would allow for the possibility of everyone one else living the same way.

Assuming I was like the average American before the No Impact experiment began, my ecological footprint was 24 acres. But worldwide, there exist only 4.5 biologically productive acres per person. In other words, if everyone were to live like the former me, we would need more than five planet earths. So, there was no possibility of everyone else in the world living the same way as me. Kant would have thought I was immoral. He would have smiled upon the No Impact project, however, Eden says.

In essence, No Impact Man reaches out (to his virtual readership) for philosophical cover for the same point he makes regarding the project's acknowledged scientific shortcomings. Indeed, this curiosity simply shows what philosophical grounds and policy implications are wrapped up with the scientific claims he is drawing on to begin with, which were always underwritten by a tacit version of Kant's categorical imperative as it informs the use of knowledge and reason. Dare to know the hidden risks. Don't take more than you use-more than your own ecological offset-means also conceiving of your actions in terms of the fashioning a universal law for perpetual ecological sustainability. Yet, because consumption equates to waste, don't waste more than use is the more appropriate if a bit perplexing formulation. You waste more than you use because you are wasting for others. With the rule of side-effects, you are always in effect using the offset of others elsewhere, both spatially and temporally. "[T]o act like your actions were passing laws in the ideal kingdom[,] the kingdom of ends," as one of No Impact Man's respondents put it, means affecting a favorable risk position that operates for all possible outcomes for everyone-down to the non-rational agents, Beck would have it in a moment of Hobbesian flourish: "in this struggle of all against all for the most beneficial risk definition, to the extent that it expresses the common good and the vote of those who themselves have neither vote nor voice (perhaps only a passive franchise for grass and earthworms will bring humanity to its senses)" (31). A whimsy that signals perhaps we have changed horses from the epistemological/ethical concerns of The First Critique to the reflexivizing aesthetic concerns of The Third Critique.

Aesthetic modernity is Scott Lash's cognate term for Beck's second modernity: “The second and importantly aesthetic modernity is not anti-rational or rational but has a principle of rationality based on reflexivity" (3). Considering this we might better understand No Impact Man's use of the term philosophy to mean philosophical cover for an aesthetic of biography, and, what he probably means by "philosophy" is "personal philosophy"-that folk psychological commonplace. Perhaps, his question is better put thus: Does the project work biographically? Can No Impact Man tell himself a story he can live with ecologically? The biographical identity of No Impact Man, as we have seen before, is an irreducible aspect of his project. For his recipe to work in all spaces and times-and I mean this not a bit facetiously-everyone would have to have a book deal in the wings. Can we then speak of a text-production-consumption offset 
scheme, 4.5 interpretively productive writer per readers, say? Finally, it is the consciousness raising potential of the project that justifies its philosophical and scientific shortcomings and indeed the excesses of its extremes.

Beck writes that "in class and stratification positions [that ruled first modernity] being determines consciousness, while in risk positions [that dominate second modernity] consciousness determines being" (23). So it is with No Impact Man:

During the course of the year, Michelle, Isabella and I will traverse the range of lifestyles from making a limited number of concessions to the environment to becoming eco-extremists. This means that when we're done, we can reenter the world of normal consumerdom equipped to decide which parts of our no impact lifestyle we're willing to keep and which ones we're not. In other words, in addition to the no impact year, we'll have figured out our way forward.

Is eco-Kant still smiling? This our/we could be certainly read as the restored universal pronoun that Jean-François Lyotard said failed-the risk society serves as a kind of the return of the repressed for metanarrative. Another, more literal reading is that the we here is, strictly speaking, No Impact Man, his wife, and his daughter (and his dog). The two possibilities are, of course, related, if you accept the terms of No Impact Man's project and given that the family unit more often than not plays the part of unenthusiastic by-standers to subjectivization in the risk society.

\section{BIBLIOGRAPHY}

BEAVAN, Colin. No Impact Man. On line at noimpactman.typepad.com.

BECK, Ulrich. Cosmopolitan Vision (Cambridge: Polity Press, 2006).

BECK, Ulrich. Risk Society: Towards a New Modernity (London: Sage, 1992).

Fight Club, Dir. David Fincher (Fox 2000 Pictures, 1999).

PALAHNIUK, Chuck. Fight Club. New York: Norton, 1996.

POWERS, Richard. Gain (New York: Farrar, Straus, and Giroux, 1998).

WILLIAMS, Jeffrey. “The Issue of Corporations: Richard Powers' Gain.” Cultural Logic 2.2 (Spring 1999). On line at eserver.org/clogic/2-2/Williamsrev.html.

\section{NOTES}

1. See, for instance, Mercer Schuchardt, You Do Not Talk About Fight Club: I Am Jack's Completely Unauthorized Essay Collection (New York: Benbella, 2008).

2. The image is visible on this website: http://www.librarything.com/work/1486091

3. The image is visible on this website: http://www.librarything.com/work/6156848/covers/

4. The image is visible on this website: http://www.librarything.com/work/6156848/covers/

5. The image is visible on this website: http://www.jobpostings.net/articleDetail.cfm?id=488 


\section{ABSTRACTS}

This essay interprets Richard Powers' sixth novel Gain with reference to the German sociologist Ulrich Beck's concept of "second modernity." The concept underscores the dispersal of risk and how it shreds promissory notes understood in "first modernity" between the future and present and the insides and outsides of the body. It argues that Beck supplies an apt interpretive framework for understanding these relationships and overcoming the categorical impasses between the two narrative words at work in Power's novel, the biographical situatedness of Laura Rowen Bodey's illness and the corporate history of the Clare conglomerate.

Cet article interprète Gain, sixième roman de Richard Powers, à la lumière du concept de «seconde modernité » proposé par le sociologue allemand Ulrich Beck. Ce concept souligne la dissémination du risque et la manière dont celle-ci invalide les marchés conclus par la « première modernité » entre l'avenir et le présent, entre l'intérieur du corps et l'extérieur. Cet article entend montrer que Beck fournit un cadre interprétatif utile à la compréhension de ces rapports, hors des impasses catégorielles que suscite l'opposition entre les deux régimes narratifs à l'œuvre dans le texte : le récit biographique, local et individuel, de la maladie de Laura Rowen Bodey, et l'histoire collective de l'entreprise Clare devenue conglomérat.

\section{INDEX}

Mots-clés: Savon, seconde modernité, société du risque, Ulrich Beck

Keywords: Risk Society, second modernity, Soap, Ulrich Beck

\section{AUTHOR}

AARON JAFFE

University of Louisville 